\title{
Hemorrhagic Shock Caused by Rupture of an Intra-Abdominal Leydig Cell Tumour: Case Report
}

\author{
Michel Gonzalez ${ }^{\mathrm{a}}$ Paolo Merlani ${ }^{\mathrm{b}}$ Jean-François Egger ${ }^{\mathrm{c}}$ \\ François Pugin $^{a}$ Philippe Morel ${ }^{a}$ \\ aDepartment of Visceral Surgery, bervice of Intensive Care, Department of \\ Anaesthesiology, Pharmacology and Intensive Care, and 'Department of \\ Pathology, University Hospital Geneva, Geneva, Switzerland
}

\section{Key Words}

Cryptorchidism · Leydig cell tumour · Hemorrhagic shock

\begin{abstract}
The rupture of an intra-abdominal testicular neoplasm is a rare cause of acute abdomen and massive intra-abdominal haemorrhage. We report the case of a 70-year-old male presenting a massive intra-abdominal bleeding caused by a Leydig cell tumour in an undescended testis. The clinical details and pathology of this rare testicular tumour are discussed.
\end{abstract}

\section{Introduction}

Cryptorchidism results from abnormal formation and descent of the testis. It is present in approximately $6 \%$ of full-term neonates and approximately $0.8 \%$ of infants at 1 year of age. After childhood an undescended testis can present complications such as cancer, ischemia and infertility. Cryptorchid testes have, compared to a normal testes, a 20 -fold increased risk to develop a testicular tumour. More than $90 \%$ of these tumours are pure seminoma [1-3]. Complications of intra-abdominal testis, such as acute abdomen caused by torsion or bleeding, are rare [6]. We describe the first case, to our knowledge, of an interstitial Leydig cell tumour developed in an undescended testis revealed by a massive intra-abdominal bleeding. 


\section{Case Report}

A 70 -year-old man presented with a 2 days abdominal pain history associated with abdominal distension and weakness. He had had myocardial infarction 7 years earlier and had not history of abdominal surgery. In the emergency room, his blood pressure was 90/60 $\mathrm{mm} \mathrm{Hg}$ and his cardiac frequency was 120 beats/min. He presented abdominal tenderness with signs of peritoneal irritation. A left lower quadrant mass was noted at physical examination. The scrotum was not examined. Laboratory findings were as follows: haematocrit $36 \%$ and white blood cell count $30.7 \times 10^{9} / 1$. The rest of the CBS and the chemistry profile were normal.

After fluid resuscitation, the patient's blood pressure normalized. A CT scan performed at this time showed an $11 \times 7 \times 6 \mathrm{~cm}$ heterogeneous mass with active bleeding localised in the left para-umbilical region in contact with the intestinal mesentery (fig. 1). Intra-abdominal liquid was present around the liver and the spleen. In the presence of an active intra-abdominal bleeding from an intra-abdominal mass we performed an angiography which did not show an active bleeding after catheterisation of all abdominal arteries.

After admission to the intensive care unit the patient presented hemodynamic instability. He was taken to the operating room. At laparotomy $2,000 \mathrm{ml}$ of blood were found in the abdominal cavity. In the left lower abdominal cavity next to the sigmoid colon attachment, an $11 \times 7 \times 6 \mathrm{~cm}$ mass with pedonculated structure presented a perforated capsule with active bleeding (fig. 2). After excision of this mass a complete abdominal exploration was performed with no evidence of other mass or suspicious lymph nodes.

Histopathologic examination revealed a testicular Leydig cell tumour. On gross examination, it was an encapsulated mass, the cut surface was lobular, soft to firm and pale yellow in colour. Microscopy revealed a tumour infiltrating the albuginea, composed of large polygonal cells with well-defined outlines, eosinophilic granular cytoplasm and round nucleus (fig. 3). Nuclear atypia and mitosis were noted and the mitotic count was 1-3/10 hpf. Large part of the tumour was necrotic. There was no vascular, lymphatic or spermatic cord invasion.

After this finding, a closer look at the patient's history revealed that he presented a non-operated cryptorchism since childhood. The patient was discharged 10 days after surgery.

\section{Discussion}

1 out of 500 adult males possesses an undescended testis that may be associated with complications such as cancer, ischemia and infertility. In the general population, a man's lifetime risk of developing a testicular malignancy is approximately $0.3-0.7 \%$. In contrast, the risk of a man with a history of cryptorchidism of developing a testicular tumour ranges from 3 to 5\%. The risk of developing a carcinoma increases if the testis is located very distant from the scrotum, i.e. particularly when it is intra-abdominal. In this case the risk of developing a testicular malignancy is 20 -fold greater than normal. Interestingly, while orchidopexy improves fertility, it does not alter the risk of developing carcinoma $[1-3]$.

Approximately $90 \%$ of these tumours are seminomas. The cancer of undescended testis peaks in the third to four decade of life. Ultrasonography, magnetic resonance imaging, computed tomography and gallium scanning are usually used in the monitoring of an intra-abdominal testis $[4,5]$.

Our case presented a very rare Leydig cell tumour in an undescended testis neglected in his childhood. Tumours arising from interstitial cells of Leydig present in the testis account for only $1.2-3 \%$ of all testicular neoplasm [6]. The reported median age of patients with this tumour is 62.1 (range 39-70) years. However, only $7-10 \%$ of such tumours will develop metastasis. The phenomenon of metastatic Leydig cells tumours has been described only in adults [7,8]. The histologic features of Leydig cell tumour have been well described in the literature. Some criteria of malignancy in the primary tumour 
have been suggested; they include marked cellular pleomorphism with atypical nuclei, numerous and atypical mitosis, invasion of the vascular or lymphatic nodes, extension of the tumour into the spermatic cord or invasion of the capsule, tumour size $>50 \mathrm{~mm}$, necrosis and mitosis $>3 / 10 \mathrm{hpf}$. In the present case, the patient presented some criteria of malignancy such as size $(>5 \mathrm{~cm})$, necrosis, atypical nuclei and invasion of the capsule. However our patient showed mitosis at $3 / 10 \mathrm{hpf}$ and no lymphatic or vascular invasion. This presentation classified our tumour as malignant with a potentially aggressive behaviour.

Generally metastatic spread occurs within 2 years of primary Leydig cell tumours, and the patient dies within 2 years of the discovery of the metastatic disease. The tumour is highly resistant to both radiation and chemotherapy [9]. It also has a great propensity for recurrence after surgical resection. In the literature no specific markers to diagnose or to monitor a Leydig cell tumour have been described. This testicular tumour can present with testicular pain or as a palpable mass. However, endocrinological features can occur in $20 \%$ of those tumours. In these cases, an increase in serum oestradiol and suppression of serum testosterone can be seen. They can present with precocious puberty, gynecomastia and infertility [10].

Acute abdomen and massive bleeding is a very rare presentation of a cryptoid testicular cancer, with 2 cases of ruptured intra-abdominal seminomas reported in the literature $[11,12]$. It is interesting to mention that Sertoli-Leydig tumours of the ovary have been reported to rupture into the abdomen [13]. To our knowledge this is the first case of such a clinical presentation in a patient with a Leydig cell tumour of an intraabdominal testis. 


\begin{tabular}{c|l|l|l}
$\begin{array}{c}\text { CaseReportsin } \\
\text { Gastroenterology }\end{array}$ & $\begin{array}{l}\text { Case Rep Gastroenterol 2007;1:53-58 } \\
\text { D0I: 10.1159/000107471 }\end{array}$ & Published online: August 20, 2007 & $\begin{array}{l}\text { @ 2007 S. Karger AG, Basel } \\
\text { ISSN 1662-0631 } \\
\text { www.karger.com/crg }\end{array}$ \\
\hline
\end{tabular}

Fig. 1. CT scan showing an intra-abdominal mass with active bleeding.

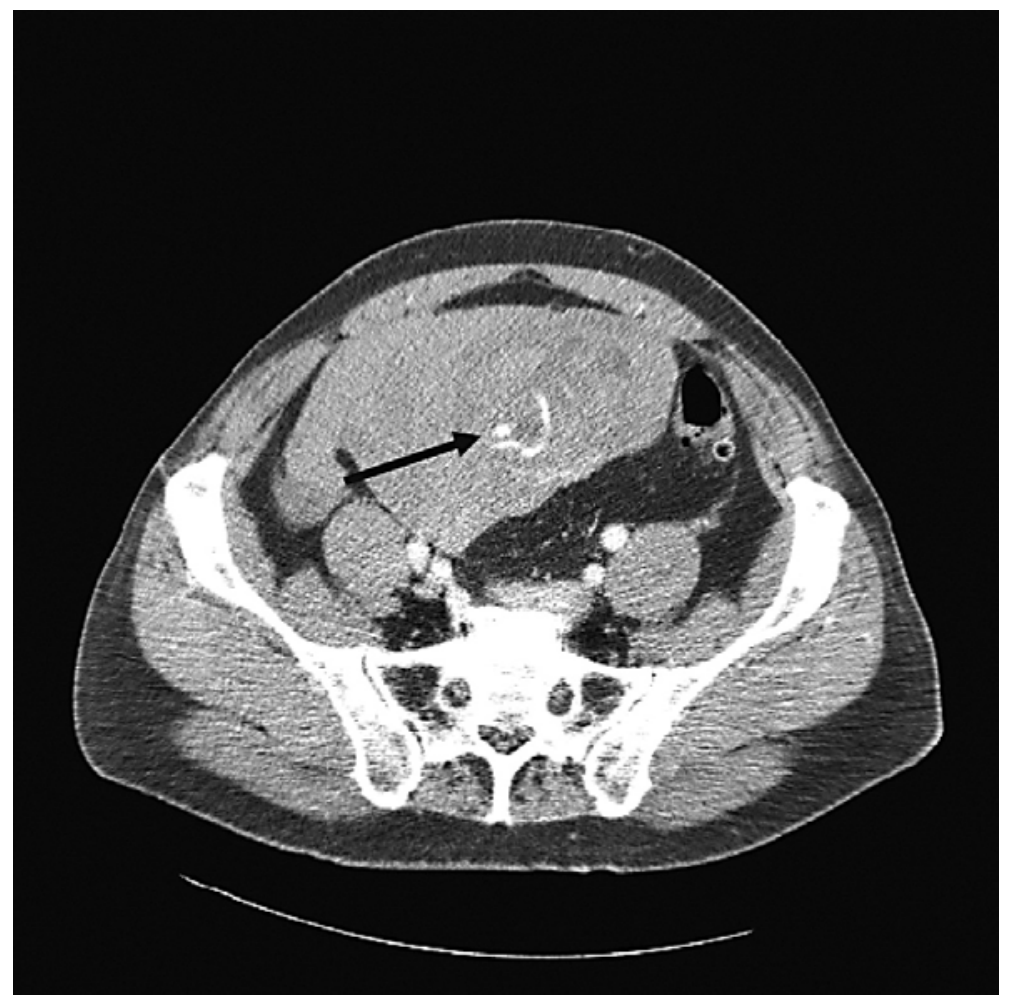

Fig. 2. Testicular mass after excision, measuring $11 \times 7 \times 6 \mathrm{~cm}$ and weighing $132 \mathrm{~g}$ with areas of hemorrhage.

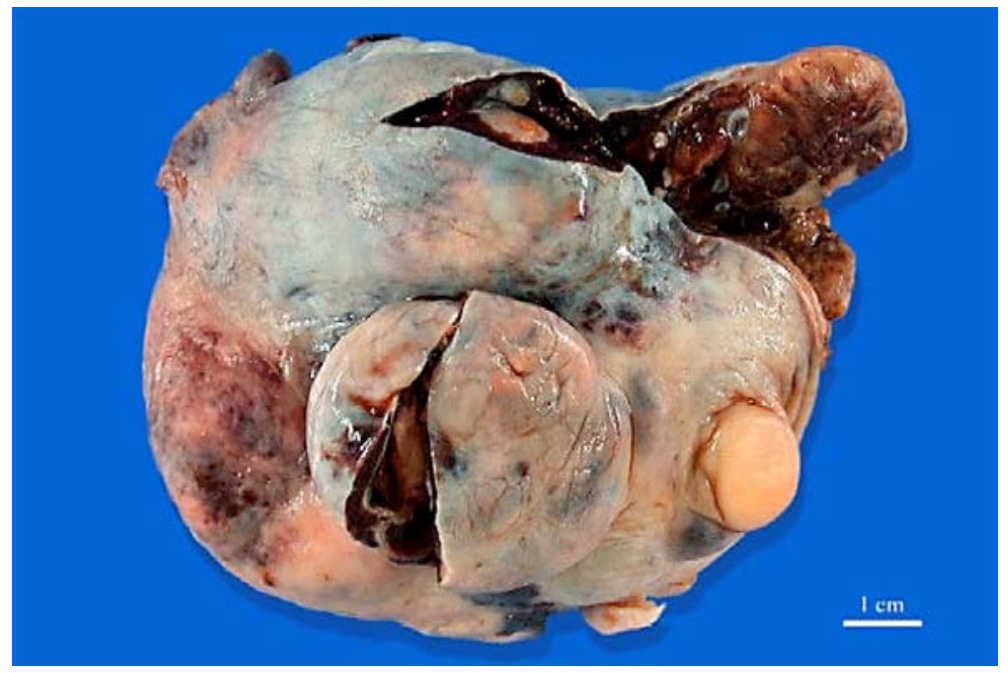




\begin{tabular}{c|l|l|l}
$\begin{array}{c}\text { CaseReportsin } \\
\text { Gastroenterology }\end{array}$ & $\begin{array}{l}\text { Case Rep Gastroenterol 2007;1:53-58 } \\
\text { D0I: 10.1159/000107471 }\end{array}$ & Published online: August 20, 2007 & $\begin{array}{l}\text { O 2007 S. Karger AG, Basel } \\
\text { ISSN 1662-0631 } \\
\text { www.karger.com/crg }\end{array}$ \\
\hline
\end{tabular}

Fig. 3. H\&E stain, $\times 600$. The neoplastic cells are large, with abundant eosinophilic cytoplasm and round nuclei.

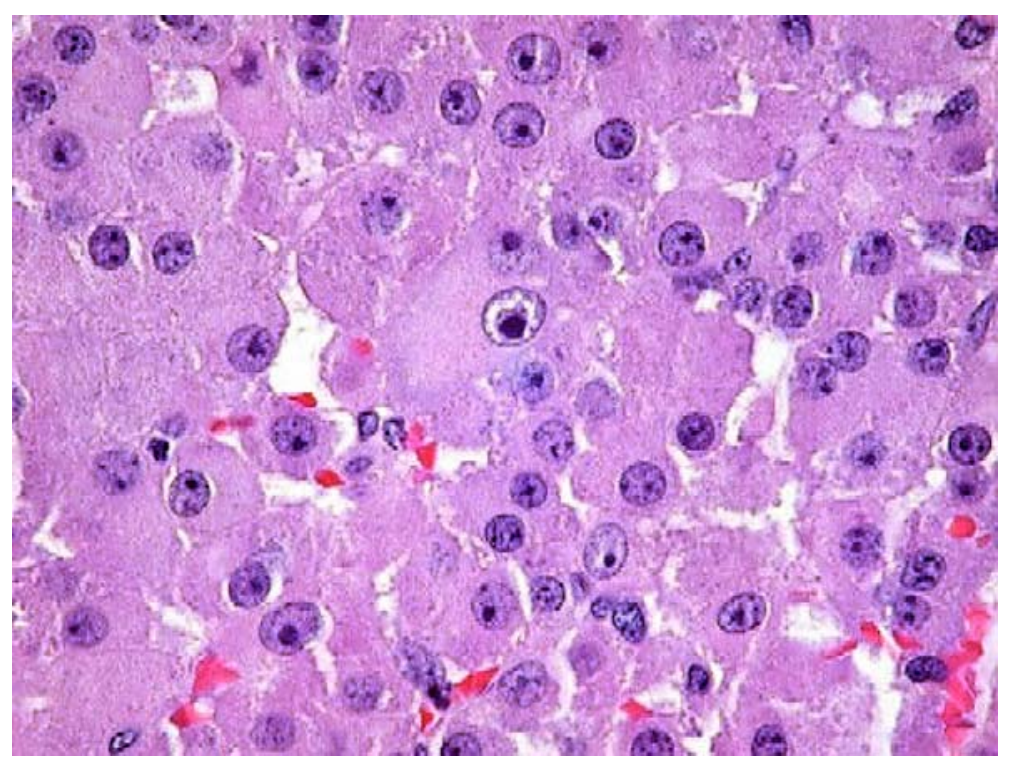




\section{References}

1 Fonkalsrud EW: Current management of undescended testis. Semin Pediatr Surg 1996;5:2-7.

2 Cortes D: Cryptorchidism - aspects of pathogenesis, histology and treatment. Scand J Urol Nephrol Suppl 1998;196:1-54.

-3 Rao AB: Seminoma in undescended testes. Br J Urol 1969;41:83-88.

4 Woodward PJ: Seminoma in an undescended testis. Radiology 2004;231:388-392.

5 Fritzsche PJ, Hricak H, Kogan BA, Winkler ML, Tanagho EA: Undescended testis: value of MR imaging. Radiology 1987;164:169-173.

6 Kim I, Young RH, Scully RE: Leydig cell tumors of the testis. A clinicopathological analysis of 40 cases and review of the literature. Am J Surg Pathol 1985;9:177-192.

7 Powari M, Kakkar N, Singh SK, Rai RS, Jogai S: Malignant Leydig cell tumour of the testis. Urol Int 2002;68:63-65.

8 Cheville JC, Sebo TJ, Lager DJ, Bostwick DG, Farrow GM: Leydig cell tumor of the testis: A clinicopathologic, DNA content, and MIB-1 comparison of nonmetastasizing and metastasizing tumors. Am J Surg Pathol 1998;22:13611367.

-9 Betram KA, Bratloff B, Hodges GF, Davidson H: Treatment of malignant Leydig cell tumor. Cancer 1991;680:2324-2329.

10 Masumori N, Kumamoto Y, Itoh N, Tsukamoto T, Miyao N, et al: Leydig cell tumor: a case report with reference to its endocrinological features. Eur Urol 1993;24:302-304.

11 Watkins GL: Massive hemoperitoneum resulting from rupture of a seminoma in an undescended testicule. J Urol 1970;103:447-448.

-12 Kuçuk HF, Dalkilic G, Kuroglu E, et al: Massive bleeding caused by rupture of intra-abdominal testicular seminoma: case report. J Trauma 2002;52:1000-1001.

-13 Evans AT, Gaffey TA, Malkasian GD, Annegers JF: Clinicopathologic review of 118 granulosa and 82 theca cell tumors. Obstet Gynecol 1980;55:231-238.

Founding or conflict of interest: none. 